smaller molecule than that in the deproteinated serum.

To the discussion of the view of WaldschmidtLeitz that the polarographically active substance in carcinomatic deproteinated serum may be a sulphurfree mucoid ${ }^{4}$, I would point out that this assumption is not in accord with my experimental facts; the hydrolysates of the deproteinated serum solutions in question show clearly the presence of cystine and, moreover, in the same relative content as found in the various non-hydrolysed deproteinated pathological or normal sera; the cystine content in the deproteinated serum is of the order of $10^{-4}$ molar, and is always higher in the carcinomatic case; against the necessity for a mucoid theory is also the fact that an identical polarographic effect is evoked by a deproteinated solution of pure crystalline albumin, if the albumin is first degradated with the alkali or pepsin ${ }^{5}$.

The experimental evidence thus shows convincingly that the changes in pathological sera polarographically detected consist in a proteolytic degradation of serum proteins by which eystine containing high molecular products, bearing the character of albumose, are split off. The origin of this proteolysis taking place in the blood must be sought in the increase of some products of the pathological metabolism, of the type of Abderhalden's proteolytic reactions.

Physico-chemical Institute,

\section{R. BRDiČKa.} Charles University, Prague.

Aug. 15.

${ }^{1}$ Brdicka, R., Acta Unio Internationalis contra Cancrum, 3, 13 (1938). ${ }^{2}$ Bergh, F., Henriques, O. M., and Wolffbrandt, C. G., Nature, 142, 212 (1938).

${ }^{3}$ Rosenthal, H. G., Mikrochemie, 22, 233 (1937).

4 Waldschmidt-Leitz, E., Angew. Chem., 51, 324 (1938).

${ }^{5}$ Brdixka, R., to be published elsewhere.

\section{Photo-ammonification of Organic Nitrogenous Compounds in the Soil}

IN recent years Gopala Rao and Dhar', Gopala Rao ${ }^{2}$ Dhar and co-workers ${ }^{3}$ and Corbet ${ }^{4}$ have shown that nitrification in soils occurs partly as a photochemical reaction under the influence of sunlight. Dhar and co-workers ${ }^{5}$ have also brought forward considerable evidence to show that fixation of atmospheric nitrogen is favoured by sunlight.

We have now found that the decomposition of various nitrogenous compounds, the so-called ammonification, occurs as a purely photochemical reaction in the presence of photocatalysts like heated soil or ignited ferric oxide. Aqueous solutions of various nitrogenous compounds were exposed to sunlight (for 30 hours) in 'Pyrex' glass flasks under sterile conditions. The amount of ammonia liberated in the decomposition process is estimated by Folin's method. The results are as given below.

\begin{tabular}{|c|c|c|}
\hline & \multicolumn{2}{|c|}{$\begin{array}{l}\text { Milligrams of ammoniacal nitrogen } \\
\text { per litre }\end{array}$} \\
\hline & $\begin{array}{l}\text { Ferric oxide as } \\
\text { photocatalyst }\end{array}$ & $\begin{array}{c}\text { Heated red soil as } \\
\text { photocatalyst }\end{array}$ \\
\hline $\begin{aligned} M / 20 & \text { g yeine } \\
,, & \text { alanine } \\
,, & \text { aspartic acid } \\
,, & \text { glutamic acid } \\
,, & \text { urea }\end{aligned}$ & $\begin{array}{r}43 \cdot 75 \\
61 \cdot 25 \\
65 \cdot 65 \\
8 \cdot 75 \\
28 \cdot 00\end{array}$ & $\begin{array}{r}13 \cdot 85 \\
14 \cdot 00 \\
17 \cdot 30 \\
7 \cdot 00 \\
12 \cdot 72\end{array}$ \\
\hline
\end{tabular}

It thus appears that many important chemical reactions in the soil can be brought about by the photochemical action of sunlight, independently of bacteria.

Further work is in progress.

$$
\begin{array}{cl}
\text { Andhra University, } & \text { G. Gopala RaO. } \\
\text { Waltair. } & \text { CH. I. VARADANam. }
\end{array}
$$

\section{Soil Science, 31,379 (1931)}

${ }^{2}$ Soil Science, 38, 143 (1934).

3 NATURE, 133, 213 (1934); 137, 462 (1936).

4 Biochem. J., 28, 1575 (1934); 29, 1086 (1935).

${ }^{5}$ Nature, 137, 629, 1000 (1936) ; 139, 648, 1060 (1936).

\section{Effect of Pyridine Compounds on the Nutrition of Staphylococcus aureus}

RECENT investigations have established the necessity of nicotinic acid (or amide) for the growth of Staphylococcus aureus ${ }^{1}$. In a previous report, it was shown that the ability of this organism to utilize compounds related to nicotinic acid is limited. We have since prepared several compounds of interest in this connexion, and the determination of their biological activity is herewith reported.

The synthetic amino acid - glucose medium of Fildes et al. ${ }^{2}$ was employed in testing the activity of the series of compounds. The compounds were tested in the presence of an excess of thiamine $(0.05$ gamma per 10 c.c. of medium) using an 18-hour culture of $S$. aureus.

Nicotinyl glycine exhibited growth-promoting activity in the same order of concentration as nicotinic acid. Trigonelline, pyridine betaine $\beta$-carboxylic acid, $\alpha$-amino pyridine, and $\alpha$-amino pyridine $\beta$-carboxylic acid, were completely inactive as growth factors for $S$. aureus. It may be of interest to recall that Ackermann ${ }^{3}$ isolated nicotinyl glycine and trigonelline from urine following the administration of nicotinic acid.

Research Division,

Maurice Landy.

S.M.A. Corporation, Aug. 25.

${ }^{1}$ Knight, B. C. J. G., Biochem. J., 31, 731 and 966 (1937). Koser, S. A., Finkle, R. D., Dorfman, A., and Saunders, F., J. Bact., 35, 6 (1938). Landy, M., Proc. Soc. Exp. Biol. Med., 38, 504 (1938).

${ }^{2}$ Fildes, P., Richardson, G. M., Knight, B. C. J. G., and Gladstone, G. P. Brit J Exp. Path. 17, 481 (1936).

${ }^{3}$ Ackermann, D., Z. Biol., 59, 17 (1912).

\section{A Saccharum - Zea Cross}

Bотн Saccharum and Zea are distinguished by the readiness with which they cross with related genera. For example, while Mangelsdorf and Reeves ${ }^{1}$ have crossed Ziea Mays with Euchlana and Tripsacum, Venkatraman and Thomas ${ }^{2}$ have crossed $S$. officinarum with a species of Sorghum and even the remotely related Bambusa ${ }^{3}$. I have also crossed $S$. officinarum with Imperata Cylindrica Beaew. and S. spontaneum $\mathrm{L}$. with Sorghum Durra and Sorghum halepense. In spite of Zea and Saccharum being in two different sections of the Gramineæ-Andropogoneas and Maydeae (Bews)-I thought it worth while to cross them, and after several attempts using many thousands of flowers of a male sterile variety (Vellai) of S. officin. arum $2 n=80=8 x$ as the female parent, and variety 